JKKP : Jurnal Kesejahteraan Keluarga dan Pendidikan

http://doi.org/10.21009/JKKP

DOI: doi.org/10.21009/JKKP.061.05

E-ISSN : 2597-4521

\title{
HUBUNGAN KEBIASAAN BELAJAR DENGAN PRESTASI BELAJAR SISWA KELAS V SDN GUGUS 1 KECAMATAAN JONGGAT KABUPATEN LOMBOK TENGAH
}

\author{
Ida Juliana Sari ${ }^{1, a)}$, Siti Istiningsih ${ }^{2, b)}$ \\ a)idajuliana748@gmail.com, b)ningistie@yahoo.co.id \\ 1) SDN Merembu Lombok Barat ${ }^{2)}$ Universitas Mataram \\ 2)Jl. Majapahit No.62, Gomong, Selaparang, Kota Mataram, Nusa Tenggara Bar. 83115
}

\begin{abstract}
Abstrak
Penelitian ini dilaksanakan untuk mengetahui 1) bagaimanakah kebiasaan belajar siswa kelas $\mathrm{V}$ di SDN Gugus 1 Kecamatan Jonggat Kabupaten Lombok Tengah, 2) bagaimanakah pestasi belajar siswa kelas V di SDN Gugus 1 Kecamatan Jonggat Tahun Pelajaran Kabupaten Lombok Tengah, dan3) apakah ada hubungan yang signifikan antara kebiasaan belajar dengan prestasi belajar siswa kelas V di SDN Gugus 1 Kecamatan Jonggat Kabupaten Lombok Tengah. Metode penelitian ini dengan metode korelasi. Populasi dalam penelitian ini yaitu siswa kelas V SDN Gugus 1 Kecamatan Jonggat yang berjumlah 117 dengan jumlah sampel 54 siswa. Teknik pengambilan sampel dilakukan dengan cara random sampling. Teknik pengumpulan data dalam penelitian ini dengan observasi, angket, dan dokumentasi yang dianalisis menggunakan analisis statistik deskriptif. Uji prasyarat analisis meliputi uji normalitas data dan uji linieritas regresi. Uji hipotesis meliputi uji korelasi Product Moment. Hasil penelitian menunjukkan bahwa: (1) kebiasaan belajar siswa kelas $\mathrm{V}$ dengan persentase $43 \%$ tergolong tinggi ; (2) prestasi belajar siswa dengan persentase $55 \%$ tergolong sangat tinggi; (3) ada hubungan yang signifikan antara kebiasaan belajar dengan prestasi belajar ditunjukkan dengan adanya thitung $<$ tabel $(0,02<0,05)$ dan taraf signifikansi 0,05 , korelasi dalam penelitian ini tergolong sedang. Simpulan dari penelitian ini adalah terdapat hubungan yang signifikan antara kebiasaan belajar dengan prestasi belajar, dan tergolong sedang. Saran guru harus memperhatikan dan memantau prestasi belajar siswa dengan memberi bimbingan dan motivasi agar lebih semangat dalam belajarnya serta siswa dapat membiasakan diri belajar secara optimal.
\end{abstract}

KataKunci: kebiasaan belajar, prestasi belajar.

\section{RELATIONSHIP OF LEARNING HABITS WITH LEARNING ACHIEVEMENTS IN CLASS V STUDENTS OF SDN GUGUS 1 KECAMATAAN JONGGAT CENTRAL LOMBOK DISTRICT}

\begin{abstract}
.
This study was conducted to find out 1) how the learning habits of fifth grade students in Ganggug 1 Elementary School, Jonggat Subdistrict, Central Lombok Regency, 2) how is the learning outcome of class $V$ students, and 3) is there a significant relationship between learning habits and the learning
\end{abstract}


achievement of fifth grade students in Cluster 1 Elementary School. The method in this study is the correlation method. The population in this study were class $V$ which numbered 117 with a sample of 54 students. The sampling technique is done by random sampling. Data collection techniques in this study by observation, questionnaire, and documentation were analyzed using descriptive statistical analysis. The analysis prerequisite test includes data normality test and regression linearity test. Hypothesis testing includes Product Moment correlation test. The results showed that: (1) the learning habits of fifth grade students with a percentage of $43 \%$ were classified as high; (2) student learning achievements with a percentage of $55 \%$ classified as very high; (3) there is a significant relationship between study habits and learning achievement indicated by the existence of tcount $<t$ table $(0.02<0.05)$ and significance of 0.05 , the correlation in this study is classified as moderate. The conclusion of this study is that there is a significant relationship between study habits and learning achievement, and is classified as moderate. Suggestions teachers must pay attention and monitor student learning achievement by giving guidance and motivation so that more enthusiasm in learning and students can get used to learning optimally.

Keywords: study habits, learning achievement.

\section{PENDAHULUAN}

Pendidikan merupakan aspek yang penting untuk menunjang kemajuan bangsa di masa depan, karena dengan pendidikan subyek pengembang (pendidik), dibina dan dikembangkan potensi-potensi yang ada padanya dengan tujuan agar terbentuk subyek-subyek pengembang yang berkualitas sesuai dengan standar nasional pendidikan. Menurut Peraturan Pemerintah No 19 tahun 2005 pasal 1 menyebutkan bahwa: Standar nasional pendidikan adalah kriteria minimal tentang pendidikan di seluruh wilayah hukum NKRI. Sedangkan menurut fungsinya yang tertuang pada PP No 19 tahun 2005 pasal 3 menyatakan bahwa: Standar nasional pendidikan berfungsi sebagai dasar dalam perencanaan, pelaksanaan dan pengawasan pendidikan dalam rangka mewujudkan pendidikan yang bermutu.

Kebiasaan belajar merupakan ciri yang di miliki setiap siswa. Mereka memiliki kebiasaan belajar yang khas yang disesuaikan dengan selera dan kondisi masing-masing individu. Berbagai kebiasaan dapat berupa cara siswa dalam mempelajari materi suatu pelajaran, kebiasaan istirahat sejenak pada saat belajar, dan sebagainya. Kebiasaan mempelajari suatu materi pelajaran antara siswa yang satu dengan yang lain berbeda-beda dalam arti ada siswa yang biasa mempelajari materi pelajaran dengan cara hafalan, adapula siswa yang lainnya yang lebih menyukai dengan memusatkan perhatiannya pada pengertian atau pemecahan suatu masalah. Dilihat dari segi bentuk belajarnya, siswa yang satu lebih suka dengan belajar berkelompok dengan temannya, namun siswa yang lain justru tidak menyukainya dengan alasan tidak bisa konsentrasi. Kenyataan tersebut semuanya bermula dari kondisi fisik dan psikis yang berbeda, latar belakang ekonomi yang tidak sama, ingatan, pikiran, daya kemampuan menyerap materi pelajaran, minat, perbedaan kebiasaan para siswa yang berbeda antara satu dengan yang lainnya.

Kebiasaan belajar merupakan salah satu faktor yang menunjang tercapainya prestasi belajar siswa, terutama yang sangat berpengaruh pada prestasi siswa adalah cara belajar. Cara belajar merupakan strategi yang dilakukan oleh siswa dalam belajarnya untuk mencapai tujuan yang diharapkan yaitu prestasi belajar yang baik. Hal ini dapat dilihat dari cara belajarnya setiap hari, disiplin waktu baik di rumah maupun di sekolah. Banyak siswa yang gagal mendapat hasil yang baik dalam pelajarannya karena tidak mengetahui cara-cara belajar yang efektif, karena itu untuk menunjang agar tujuan belajar siswa dapat tercapai maka diperlukan adanya belajar yang efektif.

Jurnal Kesejahteraan Keluarga dan Pendidikan (JKKP) Vol.06 No.01

doi.org/10.21009/JKKP.061.05 


\section{KAJIAN TEORETIK}

Menurut Djaali(2014:128) kebiasaan merupakan cara bertindak yang diperoleh melalui belajar secara berulang-ulang, yang pada akhirnya menjadi menetap dan bersifat otomatis. Sedangkan menurut Slameto (2013:82), belajar bertujuan untuk mendapatkan pengetahuan, sikap, kecakapan, dan keterampilan, cara-cara yang dipakai itu akan menjadi kebiasaan. Menurut Burghardt dalam Syah (2009:120), kebiasaan itu timbul karena proses penyusutan kecenderungan respons dengan menggunakan stimulasi yang berulang-ulang.

Dalam proses belajar, pembiasaan juga meliputi pengurangan perilaku yang tidak diperlukan. Karena proses penyusutan atau pengurangan inilah, muncul suatu pola bertingkah laku baru yang relatif menetap dan otomatis. Syah (2009:128), mengemukakan bahwa kebiasaan belajar adalah proses pembentukan kebiasaan-kebiasaan baru atau perbaikan kebiasaan yang telah ada. Tujuannya agar siswa memperoleh sikap-sikap dan kebiasaan-kebiasaan perbuatan baru yang lebih tepat dan positif dalam arti selaras dengan kebutuhan ruang dan waktu.

Pendapat lain dari Djaali (2014: 128), kebiasaan belajar dapat diartikan sebagai cara atau teknik yang menetap pada diri siswa pada waktu menerima pelajaran, membaca buku, mengerjakan tugas, dan pengaturan waktu untuk menyelesaikan kegiatan. Kebiasaan belajar merupakan suatu cara atau metode yang dilakukan oleh seseorang secara berulang-ulang, dan pada akhirnya menjadi suatu ketepatan dan bersifat otomatis. Berdasarkan pendapat-pendapat di atas dapat disimpulkan bahwa kebiasaan belajar merupakan tingkah laku yang terbentuk karena dilakukan secara berulang-ulang sepanjang hidup individu dan biasanya mengikuti cara atau pola tertentu, sehingga akan terbentuk sebuah kebiasaan belajar. Jadi, yang dimaksud dengan kebiasaan belajar di sini adalah cara-cara belajar yang paling sering dilakukan oleh siswa dan cara atau kebiasaan belajar dapat terbentuk dari aktifitas belajar, baik secara sengaja ataupun tidak sengaja.

Beberapa ahli mengemukakan pengertian belajar dalam memberikan gambaran tentang pengertian belajar. Menurut Morgan et.al. dalam Catharina (2004) menyatakan bahwa belajar merupakan perubahan relatif permanen yang terjadi karena hasil dari praktek atau pengalaman. Menurut Slameto (1995) belajar adalah suatu proses usaha yang dilakukan seseorang untuk memperoleh suatu perubahan tingkah laku yang baru keseluruhan, sebagai hasil pengalamannya sendiri dalam interaksinya dengan lingkungan. Belajar merupakan suatu proses penting bagi perubahan perilaku manusia dan ia mencakup segala sesuatu yang dipikirkan dan dikerjakan. Dari pengertian belajar di atas dapat di lihat pula beberapa pengertian prestasi belajar menurut beberapa ahli, Winkel (1996:226) mengemukakan bahwa prestasi belajar merupakan bukti keberhasilan yang telah dicapai oleh seseorang. Dengan demikian, prestasi belajar merupakan hasil maksimum yang dicapai oleh seseorang setelah melaksanakan usaha-usaha belajar.

Arif Gunarso (1993:77) mengemukakan bahwa prestasi belajar adalah usaha maksimal yang dicapai oleh seeorang setelah melaksanakan usaha-usaha belajar. Sedangkan menurut Gagne (1985:40) menyatakan bahwa prestasi belajar dibedakan menjadi lima aspek, yaitu kemampuan intelektual, strategi kognitif, informasi verbal, sikap, dan keterampilan. Prestasi belajar dibidang pendidikan adalah hasil pengukuran terhadap siswa yang meliputi faktor kognitif, afektif, dan psikomotorik setelah mengikuti proses pembelajaran yang diukur dengan menggunakan instrumen tes atau instrumen relevan. Jadi, prestasi belajar adalah hasil pengukuran dari penilaian usaha belajar yang dinyatakan dalam bentuk simbol, huruf maupun kalimat yang menceritakan hasil yang sudah dicapai oleh setiap anak pada periode tertentu. Berdasarkan penjelasan di atas, dapat disimpulkan bahwa prestasi belajar merupakan tingkat kemanusiaan yang dimiliki siswa dalam menerima, menolak, dan menilai informasi-informasi yang diperoleh dalam proses belajar mengajar. Prestasi belajar seseorangg sesuai dengan tingkat keberhasilan sesuatu dalam mempelajari materi pelajaran yang dinyatakan dalam bentuk nilai atau rapor setiap bidang studi setelah mengalami proses belajar mengajar.

Jurnal Kesejahteraan Keluarga dan Pendidikan (JKKP) Vol.06 No.01

doi.org/10.21009/JKKP.061.05 


\section{METODOLOGI PENELITIAN}

Penelitian ini merupakan penelitian korelasi, bertujuan untuk mengetahui hubungan antara kebiasaan belajar dan prestasi belajar siswa kelas $V$ Sdn Gugus 1 Kecamataan Jonggat Kabupaten Lombok Tengah. Penelitian ini tdak memberikan perlakuan, peneliti hanya ingin mengetahui hubungan dari variabel $X$ dan $Y$ dan nantinya diharapkan dapat mengubah kondisi siswa menjadi lebih baik. Populasi penelitian ini adalah seluruh siswa kelas V SDN Gugus 1 Kecamatan Jonggat Lombok Tengah yang terdiri dari 4 SDN dengan jumlah 117 siswa yang tersebar dengan rincian 32 siswa SDN Surabaya, 33 siswa SDN Manggong, 23 siswa SDN 1 Bonjeruk dan 29 siswa SDN 2 Bonjeruk. Sebagian populasi dijadikan sebagai sampel yang dipilih secara proportional random sampling, yakni pengambilan sampel dengan mempertimbangkan proporsi jumlah siswa disetiap sekolah kemudian diambil secara acak. Jumlah sampel dalam penelitian ini adalah 54 siswa.

Adapun teknik pengumpulan data yang digunakan dalam penelitian ini adalah:

1. Observasi

Hamdani (2011: 317) mengemukakan bahwa observasi merupakan salah satu bentuk teknik nontes yang biasa dipergunakan untuk menilai sesuatu melalui pengamatan terhadap objeknya secara langsung, saksama, dan sistematis. Observasi digunakan untuk melihat aktivitas kebiasaan belajar siswa pada sampel penelitian

2. Dokumentasi

Menurut Arikunto (2013:274) berpendapat dokumentasi digunakan untuk mencari data mengenai hal-hal atau variabel yang berupa, catatan, transkrip, buku, surat kabar, majalah, prasasti, notulen rapat, lengger, agenda, dan sebagainya. Sedangkan menurut Sugiyono (2009:240), "dokumen merupakan catatan peristiwa yang sudah berlalu". Pada penelitian ini, dokumentasi digunakan untuk memperoleh data nilai ulangan (kognitif) semester 2 kelas $V$ sebagai salah satu sumber untuk mengetahui bagaimana prestasi belajar siswa.

3. Kuesioner (Angket)

Sugiyono (2015:199) mendefinisikan kuesioner atau angket sebagai teknik pengumpulan data yang dilakukan dengan cara memberi seperangkat pertanyaan atau pernyataan tertulis kepada responden untuk dijawabnya, dimana subjek hanya diminta untuk memilih satu jawaban yang sesuai dengan dirinya. Penelitian ini menggunakan 2 alternatif jawaban instrumen yaitu "Ya" atau "Tidak". Angket digunakan untuk melihat pendapat siswa tentang kebiasaan belajar

Uji Instrumen dalam penelitian ini terdiri d

1. Uji Validitas

Uji yang digunakan untuk mengukur sah atau valid tidaknya suatu kuesioner

2. Uji Reliabilitas

Menurut Sugiyono (2014:354) Instrumen dikatakan dapat dipercaya (reliable) jika memberikan hasil yang tetap (konsisten). Dalam hal ini, yang dapat dipercaya merupakan datanya bukan tes instrumennya. Apabila datanya sesuai dengan kebenaran, maka berapa kalipun tetap sama hasilnya. Reliabilitas instrumen penelitian angket didapatkan dengan menggunakan penghitungan SpearmanBrown, karena instrumen dalam penelitian ini berbentuk angket yang skornya merupakan rentangan 0-1.

Sedangkan analisis data yang digunakan adalah sebagai berikut.

1. Uji Normalitas Data

Menurut Riduwan (2015:184) menjelaskan "Uji normalitas bertujuan untuk membuktikan bahwa data yang dihubungkan berdistibusi normal". Uji normalitas ini dikenakan pada hasil data angket manajemen kelas dan prestasi belajar.

2. Uji Homogenitas Varian (Uji F)

Jurnal Kesejahteraan Keluarga dan Pendidikan (JKKP) Vol.06 No.01

doi.org/10.21009/JKKP.061.05 
Uji hipotesis yang digunakan dalam penellitian ini adalah uji korelasi/hubungan. Uji korelasi merupakan rumus statistik yang digunakan untuk mengetahui hubungan antara dua buah variabel yaitu variabel bebas (independen) dengan variabel terikat (dependen) sehingga diketahui berapa besar nilai korelasi variabel $\mathrm{X}$ terhadap variabel $\mathrm{Y}$.

3. Uji Linieritas

Uji linearitas bertujuan untuk mengetahui apakah dua variabel mempunyai hubungan yang linear atau tidak secara signifikan. Uji ini biasanya digunakan sebagai prasyarat dalam analisis korelasi atau regresi linear. Pengujian pada SPSS 16.0 dengan menggunakan Test for Linearity dengan taraf signifikansi 0,05 .

4. Uji Hipotesis

Analisis untuk menguji hipotesis dilakukan dengan bantuan SPSS Versi 16.0 untuk mencari hubungan antara kebiasaan belajar dengan prestasi belajar siswa.

\section{HASIL DAN PEMBAHASAN}

\section{Hasil Uji Validitas dan Reliabilitas Instrumen}

Uji coba instrumen dilakukan pada siswa kelas V SDN 15 Cakranegara. sebanyak 20 peserta didik. Setelah di konsultasikan terdapat butir soal yang gugur dari variabel kebiasaan belajar berjumlah 34 butir soal terdapar 14 butir soal yang gugur dan tidak valid dengan rincian sebagai berikut.

Tabel 1. Hasil Uji Validitas Variabel X, rtabel 0,4444 taraf signifikan 0,05

\begin{tabular}{ccccc}
\hline Variabel & $\begin{array}{c}\text { Junlah } \\
\text { Butir } \\
\text { Semula }\end{array}$ & Nomor Butir Gugur & $\begin{array}{c}\text { Jumlah Butir } \\
\text { Gugur }\end{array}$ & $\begin{array}{c}\text { Jumlah Butir } \\
\text { Valid }\end{array}$ \\
\hline $\begin{array}{c}\text { Kebiasaan } \\
\text { Belajar }\end{array}$ & 34 & $4,6,7,9,12,15,17,20,21,24,26,29,8,34$ & 14 & 20 \\
\hline
\end{tabular}

Adapun ringkasan hasil uji Reliabilitas tersaji dalam tabel berikut.

Tabel 2. Hasil Uji Reliabilitas Variabel X rtabel 0,4444 taraf signifikan 0,05

\begin{tabular}{ccc}
\hline Variabel & Reliabilitas & Interprestasi \\
\hline Kebiasaan Belajar & 0,836 & Reliabel \\
\hline
\end{tabular}

Berdasarkan ringkasan hasil analisis tersebut dapat disimpulkan bahwa instrumen untuk variabel kebiasaan belajar berada dalam kategori sangat tinggi. Variabel dalam penelitian ini dinyatakan reliabel untuk digunakan.

\section{Data Kebiasaan Belajar}

Data Kebiasaan Belajar di Gugus I Kecamatan Jonggat diperoleh melalui penyebaran angket kepada siswa yang dijadikan sebagai sampel penelitian. Angket tersebut terdiri dari 20 butir pertanyaan dan terdiri dari 54 responden yang diisi oleh siswa. Adapun jumlah responden dalam penelitian ini berjumlah 54 siswa, dijelaskan bahwa yang berjenis kelamin laki-laki berjumlah 30 siswa sedangkan yang berjenis kelamin perempuan berjumlah 24 siswa sehingga jumlah seluruhnya adalah 54 siswa. Jumlah subjek berjenis kelamin laki-laki lebih banyak dari pada perempuan. Berikut disajikan hasil analisis data statistik deskripsi kebiasaan belajar diolah menggunakan Microsoft excel 2017 pada tabel 3:

Tabel 3. Analisis Deskripsi Penelitian Kebiasaan Belajar

Jurnal Kesejahteraan Keluarga dan Pendidikan (JKKP) Vol.06 No.01

doi.org/10.21009/JKKP.061.05 


\begin{tabular}{cc}
\hline $\mathrm{N}$ & 54 \\
Mean (M) & 14,16 \\
Median (Me) & 15 \\
Modus (Mo) & 16 \\
Nilai Maksimum & 18 \\
Nilai Minimum & 5 \\
\hline
\end{tabular}

Tabel analisis deskripsi di atas menunjukan bahwa jumlah sampel pada penelitian ini adalah 54 orang siswa, nilai rata-rata skor Kebiasaan Belajar yang diperoleh sebesar 14,16 dan skor yang paling banyak muncul (modus) adalah 16. Perolehan skor tertinggi adalah 18 dan perolehan skor terendah adalah 5.

Tabel 4.Frekuensi Kebiasaan Belajar

\begin{tabular}{cccc}
\hline Penskoran & Kategori & Frekuensi & Persentase \\
\hline $16-20$ & sangat tinggi & 26 & $41 \%$ \\
$12-15$ & Tinggi & 30 & $47 \%$ \\
$8-11$ & cukup tinggi & 3 & $5 \%$ \\
$4-7$ & Rendah & 4 & $6 \%$ \\
$0-3$ & sangat rendah & 1 & $1 \%$ \\
\hline
\end{tabular}

Berdasarkan data tersebut dapat diperoleh batasan skor kategori Kebiasaan Belajar yang sangat tinggi berada pada kisaran 16-20, tinggi 12 -15, cukup tinggi 8-11, rendah 4-7 dan sangat rendah 03, maka dapat dilihat pada tabel 5 .

\section{frekuensi}

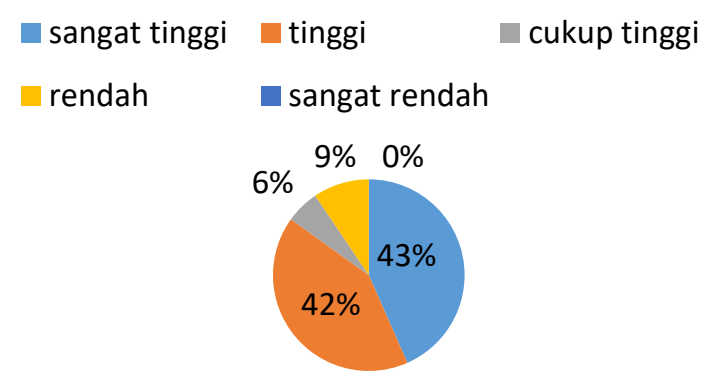

Gambar 1. Kurva Frekuensi Kebiasaan Belajar

Berdasarkan tabel di atas, dapat diketahui Kebiasaan Belajar pada kategori sangat tinggi sebanyak $26(41 \%)$ siswa, tinggi sebanyak $30(47 \%)$ siswa dan pada kategori cukup tinggi $3(5 \%)$, rendah $4(6 \%)$, sangat rendah yaitu $1(1 \%)$. Kecendrungan tersebut disajikan dalam kurva 4.5. Sehingga dapat dilihat bahwa kebiasaan belajar siswa sangat tinggi.

\section{Data prestasi belajar}

Agar mengetahui hubungan Kebiasaan Belajar dengan prestasi belajar siswa SDN di Gugus I Kecamatan Jongga Kabupaten Lombok Tengah. Maka data yang peneliti butuhkan adalah data rata-rata 
nilai rapot siswa kelas $\mathrm{V}$ semsester II. Adapun metode yang digunakan oleh peneliti adalah metode dokumentasi. Peneliti melakukan dokumentasi rata-rata nilai raport kelas $\mathrm{V}$ dari masing-masing sekolah pada tanggal 1-5 Agustus 2017. Berikut disajikan hasil analisis data statistik deskripsi prestasi belajar pada tabel 4.6 yang diolah menggunakan microsort excel 2017:

Tabel 6. Analisis Deskripsi Penelitian Prestasi Belajar

\begin{tabular}{cc}
\hline $\mathrm{N}$ & 54 \\
Mean (M) & 81,03 \\
Median (Me) & 84,5 \\
Modus (Mo) & 85 \\
Nilai Maksimum & 90 \\
Nilai Minimum & 60 \\
\hline
\end{tabular}

Tabel di atas analisis deskripsi prestasi belajar siswa menunjukan bahwa jumlah sampel pada penelitian ini sebanyak 54 orang, nilai rata-rata prestasi belajar siswa skor yang diperoleh sebesar 81,03 dan skor yang paling banyak muncul adalah 85 . Perolehan skor tertinggi adalah 90 dan perolehan skor terendahnya adalah 60 .

Selanjutnya dilakukan pengkategorian data prestasi belajar untuk menunjukkan kategori prestasi belajar pada siswa kelas V SDN di Gugus I Kecamatan Jonggat yang terdiri dari 5 kategori, yaitu sangat tinggi, tinggi,Cukup Tinggi, rendah dan sangat rendah.

Tabel 7. Frekuensi Prestasi Belajar

\begin{tabular}{cccc}
\hline Interval & Kategori & Frekuensi & Persentase \\
\hline $84-90$ & Sangat Tinggi & 29 & $55 \%$ \\
$78-83$ & Tinggi & 8 & $15 \%$ \\
$72-77$ & Cukup Tinggi & 9 & $17 \%$ \\
$66-71$ & Rendah & 2 & $9 \%$ \\
$60-65$ & Sangat Rendah & 5 & $4 \%$ \\
\hline
\end{tabular}

Berdasarkan data tersebut dapat diperoleh batasan skor kategori Prestasi Belajar yang sangat tinggi berada pada kisaran 84-90, tinggi 78-83, cukup tinggi 72-77, rendah 66-71 dan sangat rendah 60-65. Maka diperoleh hasil sebagai berikut.

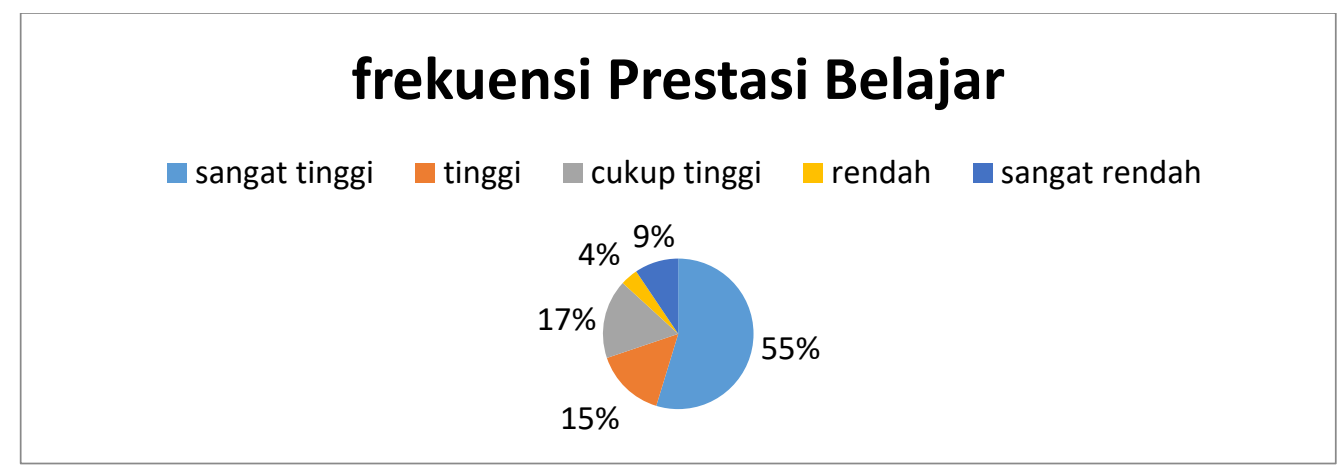

Gambar 4.8 Kurva Frekuensi Prestasi Belajar

Jurnal Kesejahteraan Keluarga dan Pendidikan (JKKP) Vol.06 No.01

doi.org/10.21009/JKKP.061.05 
Kurva di atas menunjukan gambaran prestasi belajar siswa yang dimiliki kelas V SDN di Gugus I Kecamatan Jonggat Kabupaten Lombok Tengah. Berdasarkan tabel di atas, dapat diketahui prestasi belajar siswa pada kategori sangat tinggi sebanyak 29 (55\%) siswa, tinggi sebanyak $8(15 \%)$ siswa, pada kategori cukup tinggi 9 (17\%), pada kategori rendah 2 (9\%), dan pada kategori sangat rendah 5 (4\%). Dapat dilihat bahwa prestasi belajar siswa pada kelas V SDN Gugus 1 Kecamatan Jonggat Sangat Tinggi.

\section{Hasil Analisis Data}

Adapun hasil analisis data didapatkan adalah.

\section{a. Uji Normalitas Data}

Setelah data Kebiasaan Belajar dan prestasi belajar siswa diperoleh, kemudian dilakukan uji normalitas data, uji normalitas data dilakukan untuk mengetahui apakah data Kebiasaan Belajar dan prestasi belajar siswa yang didapatkan memiliki distribusi normal atau tidak. Untuk uji normalitas data menggunakan SPSS 16.0 .

Tabel 8. One-Sample Kolmogorov-Smirnov Test

\begin{tabular}{llr}
\hline & & Unstandardized Residual \\
\hline $\mathrm{N}$ & & 54 \\
Normal Parameters & & .0000000 \\
& Mean & 3.28659045 \\
Most Extreme Differences & Std. Deviation & .175 \\
& Absolute & .125 \\
& Positive & -.175 \\
Kolmogorov-Smirnov Z & Negative & 1.290 \\
Asymp. Sig. (2-tailed) & & .072 \\
\hline
\end{tabular}

b. Test distribution is Normal.

Sehingga hasil uji nomalitas data prestasi belajar siswa diperoleh taraf signfkans $5 \%$ dengan Klomogov-Smrnov Z sebesar 1,290 dan Asymp. Sig. Sebesar 0,072 > 0,05 maka dapat disimpulkan data berdistrbusi normal dan dapat dilihat pada tabel 4.9.

\section{c. Uji Homogenitas}

Uji homogenitas dilakukan pada hasil data angket kebiasaan belajar dapat dilihat pada tabel dibawah ini.

Tabel 9. Test of Homogeneity of Variance

ANOVA

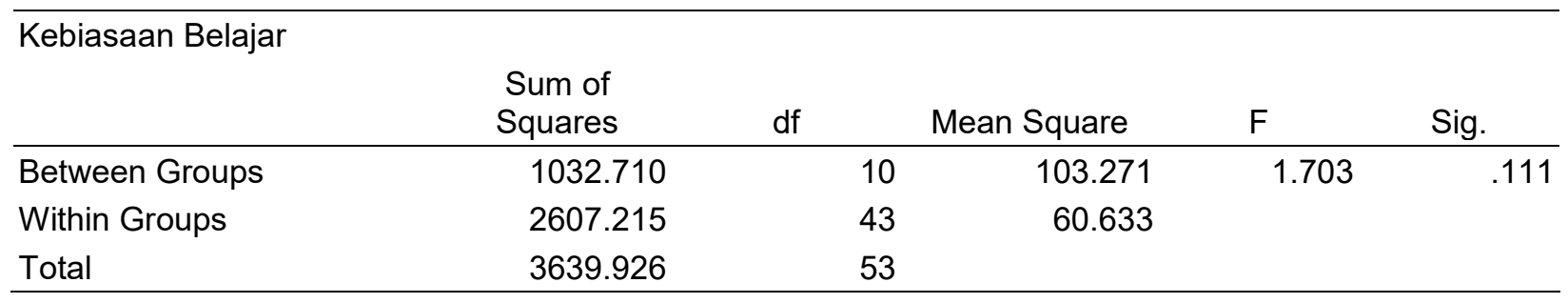

Berdasarkan uji homogenitas data manajemen kelas dengan prestasi belajar siswa diperoleh Pearson Correlation 0,42 dengan signifikansi 0,394 >0,05. Hasil ini dapat dismpulkan bahwa data tersebut homogen, karena $0,394>0,05$ 


\section{Uji Linieritas}

Uji linieritas dilakukan untuk mengetahui bentuk hubungan antara variabel bebas dan variabel terikat, yaitu kebiasaan belajar siswa dengan prestasi belajar . Jika signifikansi untuk linearity di bawah 0,05 ( $p<$ $0,05)$ dan deviation from linearity lebih besar dari 0,05 $(p>0,05)$ maka data tersebut linear. Berikut tabel output hasil analisis uji linearitas menggunakan bantuan SPSS 16.0 for Windosws

Tabel 10. Output Hasil Analisis Uji Linieritas

\section{ANOVA Table}

\begin{tabular}{|c|c|c|c|c|c|c|c|}
\hline & & & $\begin{array}{l}\text { Sum of } \\
\text { Squares }\end{array}$ & Df & $\begin{array}{l}\text { Mean } \\
\text { Square }\end{array}$ & $\mathrm{F}$ & Sig. \\
\hline \multirow{5}{*}{$\begin{array}{l}\text { prestasi } \\
\text { belajar * } \\
\text { kebiasaan } \\
\text { belajar }\end{array}$} & \multirow{3}{*}{$\begin{array}{l}\text { Between } \\
\text { Groups }\end{array}$} & (Combined) & 145.200 & 16 & 9.075 & .784 & .693 \\
\hline & & Linearity & 1.011 & 1 & 1.011 & .087 & .769 \\
\hline & & $\begin{array}{l}\text { Deviation from } \\
\text { Linearity }\end{array}$ & 144.189 & 15 & 9.613 & .830 & .640 \\
\hline & \multicolumn{2}{|c|}{ Within Groups } & 428.300 & 37 & 11.576 & & \\
\hline & \multicolumn{2}{|l|}{ Total } & 573.500 & 53 & & & \\
\hline
\end{tabular}

Hasil uji linearitas melalui program SPSS 16 dapat dilihat pada kolom linearity dan deviation from linearity di atas. Di mana pada hasil linearity untuk sig. adalah 0,769 dan deviation from linearity sig. 0,640. Dengan demikian hasil linearity untuk sig. 0,769>0,05 dan deviation from linearity sig. 0,640. Jadi dapat dikatakan data tersebut linear.

\section{Uji Hipotesis}

Tabel 11. Output Hasil Analisi Korelasi Data Varibael X dengan Variabel $Y$

\begin{tabular}{llrr}
\hline & \multicolumn{2}{c}{ Correlations } & \\
\hline \multirow{3}{*}{ kebiasaan belajar } & & kebiasaan belajar & prestasi belajar \\
& Pearson Correlation & 1 & .042 \\
& Sig. (2-tailed) & & .002 \\
prestasi belajar & $\mathrm{N}$ & 54 & 54 \\
& Pearson Correlation & .042 & 1 \\
& Sig. (2-tailed) & .002 & 54 \\
& $\mathrm{~N}$ & 54 & 5 \\
\hline
\end{tabular}

Intresprestasi hasil uji korelasi menunjukkan adanya hubungan antara kedua variabel, karena nilai sig 2 tailed diperoleh sebesar 0,02 yang berarti $<0,05$. Dimana korelasi menunjukkan nilai yang diperoleh sebesar 0,02 tersebut menunjukkan ada hubungan antara kebiasaan belajar dengan prestasi belajar siswa sehingga dapat di simpulkan bahwa Ha diterima dan $\mathrm{HO}$ ditolak yaitu, aada hubungan yang signifikan antara kebiasaan belajar dengan prestasi belajar siswa kelas V SDN Gugus 1 Kecamatan Jonggat Kabupaten Lombok Tengah. 


\section{KESIMPULAN}

Berdasarkan hasil penelitian dapat diketahui bahwa, prestasi belajar siswa sebagian besar berkategori sangat tinggi. Hal ini dibuktikan dari 54 orang siswa, 29 orang di antaranya mendapatkan ratarata nilai raport sebesar $89-90$ atau sebesar $55 \%$ berkatagori sangat tinggi, sedangkan untuk kebiasaan belajar berkategori sedang sebanyak 23 orang dari 54 orang siswa. Sehingga dapat disimpulkan bahwa semakin tinggi tingkat kebiasaan belajar akan diikuti dengan semakin tinggi tingkat prestasi belajar pada peserta didik kelas V di SDN Gugus V Kecamatan Jonggat Kabupaten Lombok Tengah. Hasil penelitian nilai rata-rata Kebiasaan Belajar adalah 14,16 sedangkan nilai rata-rata prestasi belajar adalah 81,03. Dimana hasil uji korelasi antara variabel $X$ dan variabel $Y$ adalah 0,02 dan hasil dari penelitian ini menunjukan terdapat hubungan yang positif dan signifikan antara kebiasaan belajar dan prestasi belajar di SDN Gugus I Kecamatan Jonggat Kabupaten Lombok Tengah.

\section{DAFTAR PUSTAKA}

---------. 2010. Belajar dan Faktor-faktor yang Mempengaruhi. Jakarta: Rineka Cipta.

--------. 2013. Prosedur Penelitian Pendidikan dengan Pendekatan Praktik.Jakarta: Rineka Cipta.

Anonim, 2003. Undang-Undang No.20 Tahun 2003 tentang Sistem Pendidikan Nasional. Jakarta

Arikunto, Suharsimi. 2010. Manajemen Penelitian. Jakarta:Rineka Cipta.

Djaali. 2014. Psikologi Pendidikan. Jakarta: Bumi Aksara.

Hamdani. 2011. Strategi Belajar Mengajar. Bandung: Setia Pustaka.

Slameto. 2010. Belajar dan Faktor-faktor yang Mempengaruhi. Jakarta: Rineka Cipta.

Slameto. 2013. Belajar dan Faktor-Faktor yang Mempengaruhinya. Rineka Cipta. Jakarta.

Sugiyono. 2013. Metode Penelitian Pendidikan. CV. Alfabeta. Bandung.

Sugiyono. 2013. Statistika Untuk Penelitian. Bandung: Alfabeta.

Sugiyono. 2015. Metode Penelitian Kuantitatif, Kualitatif, dan R\&D. Bandung: Alfabeta. 